\title{
BIOLOGICAL ASPECTS INVOLVED IN THE DEGRADATION OF ORGANIC POLLUTANTS
}

\author{
M.C. Diez*
}

Environmental Biotechnology Center, Scientifical and Technological Bioresource Nucleus (BIOREN) and Department of Chemical Engineering and Natural Resources, Universidad de La Frontera, PO Box 54-D, Temuco, Chile.*Corresponding author: mcdiez@ufro.cl

\begin{abstract}
Worldwide use of pesticide has increased dramatically during the last two decades. As a consequence, pesticide residues and their transformation products are frequently found in groundwater and surface waters. This review summarizes information about polycyclic aromatic hydrocarbons (PAHs), polychlorinated biphenyls (PCBs), some chlorophenols; it mainly empathizes on pesticides, their incorporation into the environment, microorganisms involved in their degradation and, some physicochemical aspects of pesticides behavior in soils. Details about residues of pesticides in groundwater and superficial water found in some foreign countries and in Chile are reported, as well. The fungal degradation of organic pollutants (xenobiotics) is considered as an effective method to remove these pollutants from the environment by a process which is currently known as bioremediation. Therefore, the degradation of pesticides by soil microorganisms with particular attention to white-rot fungi is also addressed. Finally, a simple and effective system (biobed) to minimize environmental contamination from pesticide manipulation, especially when filling the spraying equipment, a typical point source of contamination, is presented here.
\end{abstract}

Keywords: Biodegradation, white-rot fungi, pesticides, biobeds.

\section{INTRODUCTION}

In the last few decades, highly toxic organic compounds have been synthesized and released into the environment for direct or indirect application over a long period of time. Pesticides, fuels, polycyclic aromatic hydrocarbons (PAHs), polychlorinated biphenyls (PCBs), chlorophenols, and dyes are some of these types of compounds. Some synthetic chemicals are extremely resistant to biodegradation by native flora (Rochkind-Dubinsky et al., 1987) compared with the naturally occurring organic compounds that are readily degraded upon introduction into the environment. Therefore, hazardous wastes and chemicals have become one of the greatest problems of modern worldwide society.

Biological decomposition of pesticides is the most important and effective way to remove these compounds from the environment. Microorganisms have the ability to interact, both chemically and physically, with substances leading to structural changes or complete degradation of the target molecule (Raymond et al., 2001; Wiren-Lehr et al., 2002). Among the microbial communities, bacteria, fungi, and actinomycetes are the main transformers and pesticide degraders (De Schrijver and 
De Mot, 1999). Fungi generally biotransform pesticides and other xenobiotics by introducing minor structural changes to the molecule, rendering it nontoxic; the biotransformed pesticide is released into the soil, where it is susceptible to further degradation by bacteria (Gianfreda and Rao, 2004).

Among white-rot fungi, Phanerochaete chrysosporium and Trametes versicolor have become the most commonly used model organisms in lignin biodegradation studies due to their good ligninolytic properties, fast growth, and easy handling in culture (Gold and Alic, 1993; Mougin et al., 2002). The extracellular peroxidase enzyme systems employed are non-specific (Evans et al., 1994), and have been implicated in the degradation by white-rot fungi of a variety of contrasting aromatic xenobitics, including chlorophenols, pesticides and dyes (Pointing, 2001; Bending et al., 2002; Tortella et al., 2005; Rubilar et al., 2007), although the mechanisms involved are not clearly related to the ligninolytic potential of these organisms. As a way of not altering natural ecosystems, the trend in the last years has been the search and utilization of native fungi with ligninolytic potential as well as the evaluation of technologies that allow optimizing the conditions of degradation of organic recalcitrant compounds. In this respect, the white-rot fungus Anthracophyllum discolor Sp4, a Chilean native fungus, presents a high ligninolytic activity, mainly manganese peroxidase (MnP) activity, and therefore it has a great potential for xenobiotic degradation (Tortella et al., 2008).

\section{PERSISTENT ORGANIC POLLUTANTS}

Persistent organic pollutans (POPs), most of them with hydrophobic properties (HOCs), include simple aromatic compounds such as benzene, toluene, ethylbenzene and xylenes (BTEX), polycyclic aromatic hydrocarbons (PAHs), including naphthalene, phenanthrene and benzo[ $\alpha]$ pyrene, and polychlorinated biphenyls (PCBs). These compounds are poorly soluble in water, and resistant to biological, chemical, and photolytic degradation (Semple et al., 2003). Among them, compounds like pesticides, polycyclic aromatic hydrocarbons (PAHs), and polychlorinated biphenyls (PCBs) arrive to the soil from different sources and have high toxicity toward humans, plants, and animals. Soil microbial and biochemical activities are sensitive to several natural and human induced changes and may provide a helpful tool to assess soil status, its quality, and its productivity. In respect to pesticides, they may enter the soil by application events, atmospheric wet or dry deposition, foliar wash-off, and accidental spills onto soil surface or into the soil profile. Similarly, PAHs may enter the soil from several sources, such as incomplete combustion of coal, oil, petroleum, and wood; petrochemical industries; dismissed industrial sites; and effluents from vehicle and equipment cleaning and maintenance (Gianfreda and Rao, 2008).

When an organic component enters the soil, it can be subjected to transfer processes that relocate the substances without altering their structure or degradation processes. In soil, an organic compound can be weakly or strongly associated to inorganic and organic colloids through adsorption mechanisms (Bayley and White, 1970; Senesi, 1992; Cea et al., 2005; Cea et al., 2007a). It can be adsorbed by plant roots or volatilized, depending on the soil zone where it is located, and on its chemical and physical properties (Singh et al., 2004; Meade and D'Angelo, 2005; Kremer and Means, 2009). If the organic compound 
accumulates on soil surface, it can undergo photodecomposition and the process will be strongly influenced by intrinsic and extrinsic soil properties as well as by the inherent chemical structure of the compound.

The removal of POPs and HOCs from contaminated sites is a widespread environmental problem today. Bezama et al. (2008) reviewed remediation technologies for organochlorinated contaminated sites in developing countries. The authors present relevant information about the distribution of polychlorinated biphenyls (PCBs) and their quantification in different regions of Chile, soil and water contamination, and treatment technologies to eliminate the contaminants.

Synergistic solubilization of polycyclic aromatic hydrocarbons by mixed anionicnonionic surfactants has been studied by Zhu and Feng (2003). Chu and Chan (2003) studied the mechanism of the surfactant-aided soil washing system for hydrophobic and partial hydrophobic organic compounds. Other works have aimed at the effect of rapeseed oil on the degradation of polyclyclic aromatic hydrocarbons in soils by Rhodococcus wratislaviensi (Pizzul et al, 2007) and with degradation of polycyclic aromatic hydrocarbons by free and nanoclayimmobilized manganese peroxidase from A. discolor (Acevedo et al., 2010).

\section{Pesticide contamination}

Worldwide pesticide usage has increased dramatically during the last two decades, coinciding with changes in farming practices and the increasing intensive agriculture. This widespread use of pesticides for agricultural and nonagricultural purposes has resulted in the presence of their residues in various environmental matrices. Pesticide contamination of surface waters has been well documented worldwide (Table 1), and constitutes a major issue that gives rise to concerns at local, regional, national and global scales (El-Nahhal et al., 1997; Planas et al., 1997; Fatoki and Awofolu, 2005; Westbom et al., 2008). Pesticides such as atrazine, isoproturon, diuron and mecoprop are the main herbicides found in groundwater in the UK, whereas atrazine, alachlor, metolachlor, etc. were detected in ground water in other European countries and in America and Africa (Table 1).

In Chile, several pesticides are used for different proposals and are permitted currently by the legislation. Some pesticides that are used in great quantities for crop protection are chlorpyrifos, atrazine, dimethoate and isoproturon (www.sag.cl). The main features of these pesticides are presented in Table 2. Many pesticides compounds are hydrophobic or moderately hydrophobic with a complex chemical composition that is very different from hydrocarbons and their derivatives. Atrazine is a hydrophobic pesticide frequently found in monitoring pesticides in aquifers of different countries (Hallberg, 1989; Leistra and Boesten, 1989; Laabs, et al., 2002).

Few studies have been developed in relation with soil, water, and sediment contamination with pesticides in Chile (Table 3). Henriquez et al. (2006) reported that the pesticides Aldrin DDT and dieldrin were found in $41.2 \%, 32.4$ $\%$ and $29.4 \%$, respectively, of the soil samples in Nuble region. Barra et al. (2001) reported that organochlorine pesticides were found in sediment cores from four Chilean lakes in Bío-Bío Region. High concentrations of PCBs, lindane and $\mathrm{pp}^{\prime}$-DDT were detected by Focardi et al. (1996) in different locations of the Biobio river basin (central Chile)located about $5 \mathrm{~km}$ from San Pedro lagoon. 
Table 1. Residues of pesticides in groundwater and superficial water found in some countries.

\begin{tabular}{|c|c|c|c|c|}
\hline Country & Detected pesticides & Levels & Water & Ref \\
\hline \multirow{2}{*}{ Portugal } & $\begin{array}{l}\text { Lindane, atrazine, simazine, dimethoate, } \\
\text { metribuzin, endosulfan, prometryn, } \\
\text { metolachlor }\end{array}$ & $\begin{array}{l}0.22-17 \\
\mu g \mathrm{~L}^{-1}\end{array}$ & Groundwater & Barcelo (1991) \\
\hline & Quinalphos (28.8\%), Paraquat $(27,9 \%)$ & $*$ & & $\begin{array}{l}\text { Teixeira et al., } \\
(2004)\end{array}$ \\
\hline \multirow[t]{2}{*}{ Netherlands } & $\begin{array}{l}\text { Atrazine, simazine, dieldrin, propazine and } \\
\text { lindane }(\boldsymbol{\beta}+\boldsymbol{\gamma}-\mathrm{HCH})\end{array}$ & $\begin{array}{l}100-200 \\
n g ~ L^{-1}\end{array}$ & Groundwater & $\begin{array}{l}\text { Maanen et al., } \\
(2001)\end{array}$ \\
\hline & A broad list of pesticides (27) & $\begin{array}{l}* * 27 \% \\
* * * 11 \%\end{array}$ & Groundwater & $\begin{array}{l}\text { Schipper et al. } \\
\text { (2008) }\end{array}$ \\
\hline Greece & Lindane $(\gamma$-BHC), chlorpyrifos, propachlor, & $\begin{array}{l}0.005-0.01 \\
\mu \mathrm{g} \mathrm{L}^{-1}\end{array}$ & Groundwater & $\begin{array}{l}\text { Karasali et al. } \\
(2002)\end{array}$ \\
\hline Canada & $\begin{array}{l}\text { Alachlor, metalaclhor, atrazine, metribuzin, } \\
\text { cianazina. }\end{array}$ & $\begin{array}{l}0.17-0.34 \\
\mu g \mathrm{~L}^{-1}\end{array}$ & Superficial & $\begin{array}{l}\text { Goss et al. } \\
(1998)\end{array}$ \\
\hline England & $\begin{array}{l}\text { Lindane }(\alpha+\beta-\mathrm{HCH}) \text {, heptachlor, Aldrin, } \gamma- \\
\text { Chlordane, endosufan, dieldrin, endrin, } 2,4^{\prime}- \\
\text { DDT, etc. }\end{array}$ & $\begin{array}{l}5.5-160 \\
n g ~ L^{-1}\end{array}$ & Superficial & $\begin{array}{l}\text { Fatoki and } \\
\text { Awofolu (2005) }\end{array}$ \\
\hline $\begin{array}{l}\text { South } \\
\text { Africa }\end{array}$ & $\begin{array}{l}\text { Lindane }(\alpha+\beta-\mathrm{HCH}) \text {, heptachlor, aldrin, } \gamma- \\
\text { Chlordane, endosufan, dieldrin, endrin, } 2,4^{\prime}- \\
\text { DDT, etc. }\end{array}$ & $\begin{array}{l}6-80 \\
\operatorname{ng~L} L^{-1}\end{array}$ & Superficial & $\begin{array}{l}\text { Fatoki and } \\
\text { Awofolu (2005) }\end{array}$ \\
\hline Brazil & $\begin{array}{l}\text { Alachlor, atrazine, chlorothalonil, } \\
\text { endosulfan, simazine, metribuzin, } \\
\text { monocrotofos, malathion, chlorpyrifos, } \\
\text { metribuzin, etc. }\end{array}$ & $\begin{array}{c}0.001-0.174 \\
\mu \mathrm{g} \mathrm{L}^{-1}\end{array}$ & $\begin{array}{l}\text { Superficial, } \\
\text { River, Lakes }\end{array}$ & $\begin{array}{l}\text { Laabs, et al. } \\
(2002)\end{array}$ \\
\hline Spain & $\begin{array}{l}\text { Atrazine, desethylatrazine, simazine, } \\
\text { desethylsimazine, metolachlor, } \\
\text { desethylterbuthylazine, terbuthylazine, } \\
\text { metalaxyl }\end{array}$ & $\begin{array}{l}\text { Up to } 0.63 \\
\text { Up to } 2.46\end{array}$ & $\begin{array}{l}\text { Superficial } \\
\text { Groundwater }\end{array}$ & $\begin{array}{l}\text { Hildebrandt et } \\
\text { al. (2008) }\end{array}$ \\
\hline Hungary & $\begin{array}{l}\text { Acetochlor, atrazine, carbofuran, diazinon, } \\
\text { fenoxycarb, metribuzin, phorate, prometryn, } \\
\text { terbutryn, and trifluralin }\end{array}$ & $* * 59 \%$ & Superficial & $\begin{array}{l}\text { Maloschik et al. } \\
2007\end{array}$ \\
\hline USA & $\begin{array}{l}\text { Data from } 10 \text { years of study } \\
\text { ( } 25 \text { pesticides) }\end{array}$ & - & $\begin{array}{l}\text { Groundwater } \\
\text { Streams }\end{array}$ & Gilliom, 2007 \\
\hline
\end{tabular}

* Represent positive cases of intoxication;

** Percentage of the samples containing pesticide;

*** Percentage of samples exceeding $0.1 \mu \mathrm{g} \mathrm{L} \mathrm{L}^{-1}$. 
Table 2. Characteristics of the pesticides with major frequency of use in Chile.

\begin{tabular}{|c|c|c|c|c|c|}
\hline Activity & Classification & \multirow{3}{*}{$\begin{array}{c}\mathbf{t}_{\mathbf{1} / 2} \text { días } \\
264\end{array}$} & $\begin{array}{c}\text { Water } \\
\text { Solubility }\end{array}$ & \multirow[t]{2}{*}{ Koc } & \multirow[t]{2}{*}{$\begin{array}{c}\text { Sales* } \\
(\%)\end{array}$} \\
\hline Insecticides-Acaricides & & & & & \\
\hline Mineral oil & - & & & & 36.94 \\
\hline Chlorpyrifos (II) & Organophosphate & $60-120$ & $1.4 \mathrm{mg} \mathrm{L}^{-1}$ & 125 & 9.86 \\
\hline Cartap hydrochloride (II) & Carbamate & 3 & $200 \mathrm{~g} \mathrm{~L}^{-1}$ & $\mathrm{ni}$ & 7.06 \\
\hline Diazinon (I) & Organophosphate & 9 & $60 \mathrm{mg} \mathrm{L}^{-1}$ & $413-760$ & 5.21 \\
\hline Azinphosmethyl (I) & Organophosphate & 87 & $28 \mathrm{mg} \mathrm{L}^{-1}$ & 882 & 3.9 \\
\hline Methamidophos (I) & Organophosphate & 4 & $200 \mathrm{~g} \mathrm{~L}^{-1}$ & $1-5$ & 3.52 \\
\hline Esfenvalerate (I) & Pyrethroid & 44 & $0.002 \mathrm{mg} \mathrm{L}^{-1}$ & 5300 & 3.37 \\
\hline Methyl bromide (I) & Organobromine & 55 & $13200 \mathrm{mg} \mathrm{L}^{-1}$ & 39 & 1.37 \\
\hline Dimethoate (II) & Organophosphate & $2-4$ & $25 \mathrm{~g} \mathrm{~L}^{-1}$ & $16-52$ & 0.97 \\
\hline Carbofuran (I) & Carbamate & $30-60$ & $320 \mathrm{mg} \mathrm{L}^{-1}$ & $17-28$ & 0.9 \\
\hline \multicolumn{6}{|l|}{ Fungicides-bactericides } \\
\hline Sulphur & Sulphur & & & & 62.21 \\
\hline Copper oxychloride (III) & Copper & 10.000 & $1.19 \mathrm{mg} \mathrm{L}^{-1}$ & - & 2.9 \\
\hline Chlorothalonil (IV) & Chloronitrile & $5-36$ & $0.9 \mathrm{mg} \mathrm{L}^{-1}$ & $300-7000$ & 1.84 \\
\hline Captan (IV) & Dicarboximide & 1 & $3.3 \mathrm{mg} \mathrm{L}^{-1}$ & 97 & 0.6 \\
\hline Carbendazim (IV) & Benzimidazol & $25-500$ & $8 \mathrm{mg} \mathrm{L}^{-1}$ & $200-250$ & 0.06 \\
\hline \multicolumn{6}{|l|}{ Herbicides } \\
\hline Glyphosate (IV) & Organophosphate & $3-60$ & $12 \mathrm{~g} \mathrm{~L}^{-1}$ & $\mathrm{ni}$ & 58.83 \\
\hline MCPA, amine salt (II) & $\begin{array}{l}\text { Methylphenoxyace } \\
\text { tic }\end{array}$ & $<7$ & $734 \mathrm{mg} \mathrm{L}^{-1}$ & ni & 2.05 \\
\hline Paraquat (I-II) & Bipyridin & $\begin{array}{c}3000- \\
5000\end{array}$ & $700 \mathrm{~g} \mathrm{~L}^{-1}$ & 1000000 & 3.44 \\
\hline Atrazine (III) & Triazine & $35-50$ & $33 \mathrm{mg} \mathrm{L}^{-1}$ & $39-155$ & 1.8 \\
\hline 2,4-D / picloram (II) & $\begin{array}{l}\text { Phenoxyacetic/AcP } \\
\text { yridincarboxilic }\end{array}$ & $\begin{array}{c}7 / 30- \\
300\end{array}$ & $500 \mathrm{mg} \mathrm{L}^{-1}$ & $20-60$ & 0.43 \\
\hline Simazine (IV) & Triazine & $70-110$ & $6.2 \mathrm{mg} \mathrm{L}^{-1}$ & $103-377$ & 2.67 \\
\hline Metsulfuron methyl (IV) & Sulfonylurea & 10 & $2790 \mathrm{mg} \mathrm{L}^{-1}$ & 40 & 2.68 \\
\hline Diuron (II) & Phenylurea & $90-180$ & $42 \mathrm{mg} \mathrm{L}^{-1}$ & 400 & 0.38 \\
\hline Diclofop-methyl & Phenoxypropionic & $23-123$ & $0-8 \mathrm{mg} \mathrm{L}^{-1}$ & 16.000 & 0.06 \\
\hline
\end{tabular}

*Sales in 2006. Information obtained from SAG (2006).; ni: no information; I: Extremely dangerous; II: Moderately dangerous; III: Scantily dangerous; IV: Not dangerous 
Table 3. Residues of pesticides in water and sediments detected in Chile.

\begin{tabular}{|c|c|c|c|c|}
\hline Place & Detected pesticides & Levels & Sample & Ref. \\
\hline $\begin{array}{l}\text { Aconcagua } \\
\text { River }\end{array}$ & $\begin{array}{l}\text { Lindane, diazinon, oxifluorphen, dicofol, } \\
\text { azinfos-methyl, metabenzotiazuron, } \\
\text { lenacil , diflubenzuron, atrazine }\end{array}$ & $\begin{array}{l}0.1-1.12 \\
\mu \mathrm{g} \mathrm{L}\end{array}$ & Water & $\begin{array}{l}\text { Baéz et al. } \\
\text { (1996) }\end{array}$ \\
\hline Traiguen River & $\begin{array}{l}\text { Simazine, 2,4-D, pichloram, hexazinone, } \\
\text { carbendazim }\end{array}$ & $\begin{array}{l}0.2-9.7 \\
\mu g \mathrm{~L}^{-1}\end{array}$ & Water & $\begin{array}{l}\text { Palma et al. } \\
\text { (2004) }\end{array}$ \\
\hline $\begin{array}{l}\text { San Pedro lake } \\
\text { Lleu-Lleu, } \\
\text { Icalma }\end{array}$ & $\begin{array}{l}\text { Heptachlor, aldrin, endrin, pp'-DDT, } \\
\text { pp'-DDE, pp'-DDD }\end{array}$ & $\begin{array}{c}1.68-0.89 \\
\mathrm{ng} \mathrm{g}^{-1}\end{array}$ & Sediments & $\begin{array}{l}\text { Barra et al. } \\
(2001)\end{array}$ \\
\hline Chillan River & $\begin{array}{l}\text { Heptaclor, endrin, endosulfan, } \\
\text { metoxichlor }\end{array}$ & $\begin{array}{l}35-58 \\
n g L^{-1}\end{array}$ & Water & $\begin{array}{l}\text { Cooman et al. } \\
(2005)\end{array}$ \\
\hline $\begin{array}{l}\text { Limari River } \\
\text { basin }\end{array}$ & $\begin{array}{l}\text { 2,4 D, Aldicarb, atrazine }+ \text { N-dealkyl } \\
\text { metabolites, captan, carbofuran, } \\
\text { chlorothalonil, cyanazine, dimethoate, } \\
\text { diclofop-methyl, parathion, } \\
\text { pentachlorophenol, simazine, trifularine }\end{array}$ & $\begin{array}{l}1-0.05 \\
\mu \mathrm{g} \mathrm{L} \mathrm{L}^{-1}\end{array}$ & Water & DGA (2004) \\
\hline
\end{tabular}

\section{Pesticides in soil}

How long the pesticide remains in the soil depends on how strongly it is bound by soil components and how readily it is degraded, and it also depends on the environmental conditions at the time of application, e.g., soil water content (Arias-Estévez et al., 2008). A complete review about the mobility and degradation of pesticides in soils and groundwater resources pollution was provided by Arias-Estévez et al., 2008. The review shows the influence of the physical and chemical characteristics of the soil system, such as moisture content, organic matter and clay contents, and $\mathrm{pH}$, on the sorption/desorption and degradation of pesticides and their access to groundwater and surface waters. Future prospects to develop microbially derived pesticides, and new application techniques not only for reducing the dose, which can be a very effective way to minimize transport and emission, but also to avoid a resistance build-up in target organisms, are also addressed in the review.

The adsorption and mobility of organic pesticides in soils depend on the ionic or neutral character of the molecule, on its water solubility and its polarity as well as on the content and nature of the colloidal fraction of the soil, clay and organic matter (Shawhney and Brown, 1989). Adsorption and desorption of pesticides on soils are the main retention phenomena that determine their transport, transformation, and biological effects in soil environments (Barriuso et al., 1994). For example, atrazine is moderately up to highly mobile in soils, especially where soils have low clay or organic matter content (Barriuso and Calvet, 1992). Atrazine is primarily retained on silicate clays by physical adsorption but both physical adsorption and chemisorption 
contribute to the retention of atrazine by soil organic matter (Laird et al., 1994). Rama and Ligy (2008) evaluated adsorption and desorption characteristics of lindane, methyl parathion and carbofuran in soil and they reported that clay content and organic matter played a significant role in pesticide adsorption and desorption processes. Alister et al. (2008) studied the persistence, adsorption and movement of flumioxazin in soil in four Chilean vineyard production areas. The authors found that flumioxazin is an herbicide with low environmental risk owing to its short $\mathrm{DT}_{50}$, reduced soil residues 3 months after application and low effective dose.

Insecticide adsorption by soils and lake sediments has been shown vary with type of pesticide, $\mathrm{pH}$, temperature, clay and organic matter content (El-Nahhal et al., 2001). Clausen and Fabricious (2002) studied atrazine, isoproturon, mecoprop, 2,4-D and bentazone adsorption onto iron oxides. They found that acidic pesticide adsorption is strongly affected by $\mathrm{pH}$ and $\mathrm{CaCl}_{2}$ concentration in solution. Boivin et al. (2005) evaluated the adsorption and desorption of trifluralin, 2,4-D, isoproturon, atrazine and bentazone in thirteen agricultural soils. They reported that atrazine, isoproturon and trifluralin adsorption on soil was correlated to soil organic matter content and bentazone adsorption was governed by soil $\mathrm{pH}$.

According to Taylor and Spencer (1990), the two main environmental factors that affect pesticide behavior in soil are moisture and temperature, with moisture having a more significant relative weight than soil temperature. However, Bromilow et al. (1999) observed that soil moisture did not influence the degradation rate of flutriafol, epoxiconazole, propiconazole, triadimefon and triadimenol fungicides. With their experiments, the authors identified an opposite relationship between soil temperature and the degradation rate of these five fungicides. Awasthi and Prakash (1997) evaluated the fate of chlorpyrifos in soils under different moisture regimes. The major environmental factors that influenced chlorpyrifos loss in soil were moisture, $\mathrm{pH}$, organic matter and clay content. Chlorpyrifos was degraded rapidly in all air-dry soils and slightly more slowly in soils at field capacity and/or under submerged conditions.

The temperature is another factor that can affect pesticide behavior in soil. Paraíba and Spadotto (2002) reported that atrazine and lindane behave as hazardous chemicals in sites where soil temperature is low or very low, with top soil temperature less than $20{ }^{\circ} \mathrm{C}$. Brücher and Bergström (1997) determined that linuron sorption to three different agricultural soils was dependent on temperature. Paraiba et al. (2003) reported that soil temperature affected thirty pesticides' leaching potential into groundwater and indicated that contamination by these compounds varies with different climatic conditions.

Many investigators have noted that $\mathrm{pH}$ plays an important role in the adsorption of compounds with acidic functional groups on activated carbon and soil because the neutral and ionic forms display very different adsorption properties (Kookana and Rogers, 1995; Diez et al., 1999; Diez et al., 2005; Cea et al., 2005; Cea et al., 2007a). However, chlorophenol sorption in soil has been generally described assuming hydrophobic partitioning of the neutral species to soil organic matter (DiVicenzo and Sparks, 2001). In a variable-charge soil (Andisol), Diez et al., 1999 demonstrated that the adsorption of phenolic compounds from kraft mill effluent increased with decreasing $\mathrm{pH}$, possibly as a consequence of electrostatic 
repulsions between the organic compound and the resulting negative surface charge as $\mathrm{pH}$ increases. The same behavior was observed by Cea (2006) when evaluating the effect of soil $\mathrm{pH}$ of an Andisol from Southern Chile on three chlorophenols frequently found in industrial processes (Figure 1).

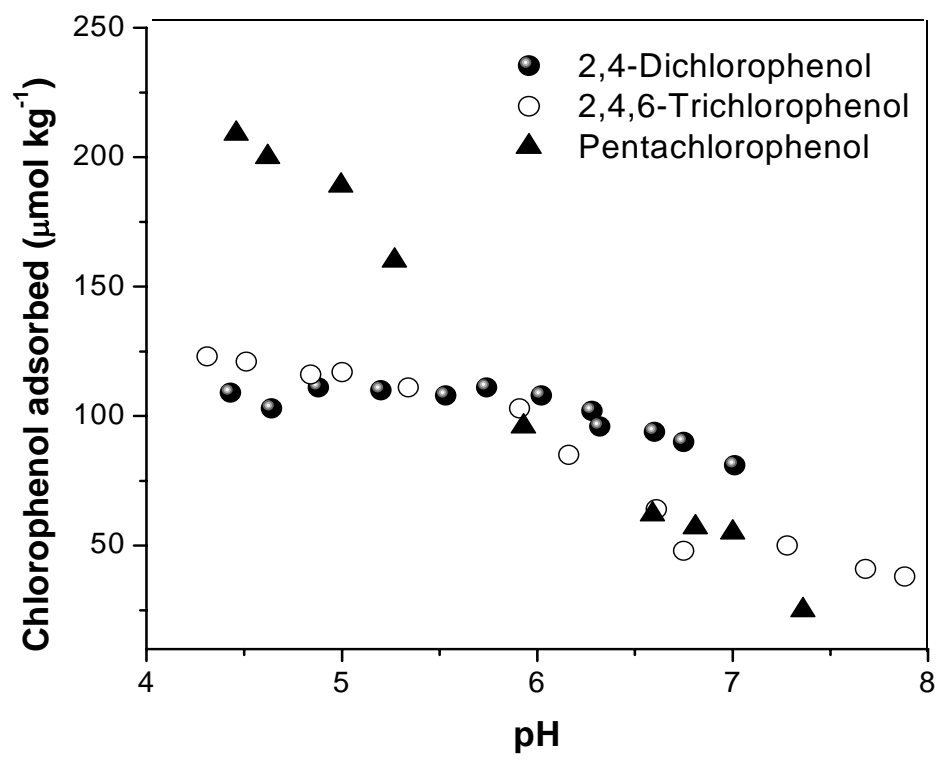

Figure 1. Effect of soil $\mathrm{pH}$ on chlorophenols adsorption at $25^{\circ} \mathrm{C}$, in $\mathrm{KCl} 0.1 \mathrm{~mol} \mathrm{~L}^{-1}$ (Cea, 2006).

An exhaustive review on the current state of knowledge regarding the formation and biological/environmental significance of bound pesticide residues in soils was provided by Gevao et al. (2000). The authors defined various terms used in the discussions identifying the types/classes of pesticides which may be added to soil and interact with it. They considered various soil properties and aspects of land management which will influence nature and degree of the soil-pesticide association, and discussed the possible physical and chemical binding mechanisms. They also took into account the role of microorganisms and other forms of soil biota in bound residue formation and the bioavailability of soilborne pesticide residues.

\section{DEGRADATION OF PESTICIDES BY SOIL MICROORGANISMS}

Several works have reported that native microorganisms from soil and sediment are capable of degrading pesticides. Eizuka et al. (2003) evaluated ipconazole (triazole fungicide) degradation by soil microorganisms. They reported that bacteria, Actinomycetes and fungi were responsible for the degradation of this compound. Singh et al. (2008) isolated a native fungal strain from corn field soil able to use atrazine as source of 
nitrogen. The fungus degraded $44 \%$ of atrazine in 20 days. Chlorpyrifos has been reported to be resistant to enhanced degradation which was attributed to the antimicrobial activity of 3,5,6-trichloro-2pyridinol (TCP) (Racke et al., 1988). However, Venkata Mohan et al. (2004) studied the degradation of a chlorpyrifos contaminated soil using native mixed microflora in slurry bioreactor at 3000 $\mu \mathrm{g} / \mathrm{g}, 6000 \mu \mathrm{g} \mathrm{g}^{-1}$ and $12000 \mu \mathrm{g} \mathrm{g}^{-1}$. They found that $91 \%, 82 \%$ and $14 \%$ of chlorpyrifos was respectively degraded after 72 h. Yu et al. (2006) isolated and characterized a fungal strain capable of degrading chlorpyrifos utilizing the pesticide as sole carbon and energy. They reported that the fungus was able to degrade $>80 \%$ of chlorpyrifos.

Pesticides are usually applied simultaneously or one after another for crop protection, and this type of pesticide application often leads to a combined contamination of pesticide residues in the soil environment. A laboratory study was conducted to investigate the influence of chlorothalonil on chlorpyrifos degradation and its effects on bacterial, fungal, and Actinomycete soil populations (Chu et al., 2008). Chlorpyrifos degradation was not significantly altered by its combination with chlorothalonil. However, the inhibitory effect of chlorpyrifos on soil microorganisms was increased by its combination with chlorothalonil, and the increase was related to the added chlorothalonil levels. Compared with those in the controls, the populations of bacteria, fungi, and Actinomycetes were significantly reduced by chlorpyrifos alone, and the inhibition increased with chlorothalonil addition. The results suggested that combined effects should be taken into account to assess the actual impacts of pesticide applications.

A review of Briceño et al. (2007) shows that various bacteria and fungi present in soils has the capacity to degrade or mineralize several pesticide groups. The studies show that addition of organic amendment and nutrients can affect mainly the adsorption, movement, and biodegradation of pesticides.

Repeated application of pesticides in the same field for a certain number of years developed an active microbial population in soil with the ability to degrade determined compounds (Hernández et al. 2008). Pesce and Wunderlin (2004) reported the biodegradation of lindane by a native bacterial consortium isolated from contaminated soil. These authors reported that $B$. thiooxidans and S. Paucimobilis degraded lindane after 3 days of aerobic incubation. Mercadier et al. (1997) reported that $50 \%$ of fungicide iprodione was degraded by bacterial isolated from soil as Pseudomonas sp. Atrazine, monocrotophos, alachlor and 4chlorophenol have been degraded also by soil microorganism (Westerberg et al., 2000; Bhadbhade et al., 2002; Strong et al., 2002). Guerin (1999) studied the natural attenuation of a low mobility insecticide, endosulfan, in low and high level contaminated soil, but the mineralization did not play any important role in natural attenuation of endosulfan by soil microorganisms. Chirnside et al. (2007) studied an indigenous microbial consortium isolated from contaminated soils to evaluate its potential to degrade atrazine and alachlor. They determined that the indigenous microbial consortium was capable of degrading both herbicides, but the consortium exhibited a unique degradation pattern being atrazine degradation dependent on alachlor degradation.

Many Actinomycetes can degrade different pollutants, including several pesticides. A review by De Schrijver and De Mot (1999) showed that the genera Arthrobacter, Clavibacter, Nocardia, Rhodococcus, Nocardioides, and 
Streptomyces behave as pesticide degrading Actinomycetes. The metabolic pathway for pesticide degradation by Actinomycetes has not been studied extensively; however, it is known that these microorganisms can produce extracellular enzymes that degrade a wide range of complex organic compounds. A common feature of the aerobic Actinomycetes is the presence of many types of monooxygenases and dioxygenases (Larkin et al., 2005). Most recent studies have isolated and characterized different Actinomycetes capable of degrading pesticides and many strains of this group are proposed to be used for soil decontamination (Benimeli et al., 2003). Benimeli et al. (2008) studied the lindane bioremediation ability of Streptomyces sp. M7 in soil samples and the pesticide effects on maize plants seeded in lindane-contaminated soil previously inoculated with Streptomyces sp. M7. Results showed that Streptomyces sp. increased the biomass and concomitantly decreased residual lindane. The activity of this strain was not inhibited by natural soil microbial flora and its growth was not inhibited by high pesticide concentration.

\section{White-rot fungi for persistent organic pollutants degradation}

A critical review of the present state of fungal activities on environmental pollutants, fungal diversity, the use of fungi in the degradation of chemical pollutants, enzyme degrading systems and perspectives on the use of fungi in bioremediation and unexplored research was reported by Tortella et al. (2005). The authors summarize information from fundamental works that reveal that a wide variety of fungi are capable of degrading an equally wide range of toxic chemicals. The capacity of non-ligninolytic and ligninolytic fungi in the bioremediation of polycyclic aromatic hydrocarbon (PAHs), benzene - toluene - ethylbenzene - xylene (BTEX), chlorophenols, polychlorinated biphenyl, munitions waste and pesticides have been discussed. Besides, several extracellular enzymes are involved in the metabolism of xenobiotic compounds as well as other factors related to these processes. Pointing (2001) presents evidence for the involvement of ligninolytic enzymes in white-rot fungal degradation of munitions waste, pesticides, polychlorinated biphenyls, polycyclic aromatic hydrocarbons, bleach plant effluent, synthetic dyes, synthetic polymers, and wood preservatives.

D'Annibale et al. (2005) studied the degradation of aromatic hydrocarbons by white-rot fungi ( $P$. chrysosporium NRRL 6361 and Pleurotus pulmonarius CBS 664.97) in a historically contaminated soil. They reported a total removal of some PAHs (naphtalene, tetrachlorobenzene, and dichloroaniline isomers, diphenylether and N-phenyl-1naphtalenamine), and a significant release of chloride ions in fungal-treated soil, in comparison with that recorded in the control microcosm. Both fungi led to a marked soil detoxification, even in the presence of a high residual concentration of the main components of the aromatic hydrocarbons fraction.

A survey of the mutual interactions establishing in a soil among xenobiotic substances with particular reference to pesticides and polycyclic aromatic hydrocarbons and microbial and enzymatic soil activities has been reviewed by Gianfreda and Rao (2008). On the other hand, Rubilar et al. (2008) analyzed the presence of chlorophenols in the environment, their main chemical and physical properties, and the main processes in their degradation by whiterot fungi with particular attention to soil environment. The reactions involved in the process, the intermediary products, the 
factors that may affect the fungal transformation of chlorophenols, and the possible applications for environmental purposes of both the whole fungal cells and/or their enzymes as isolated catalytic agents are also addressed. The biological agents involved in the bioremediation of soils contaminated with persistent organic compounds have also been analyzed by Gianfreda et al. (2006).

White-rot fungi (Basidiomycetes) are the only known organisms capable of degrading lignin extensively to $\mathrm{CO}_{2}$ and $\mathrm{H}_{2} \mathrm{O}$ in a pure culture. These organisms are able to degrade all the major wood polymers: cellulose, hemicellulose, and lignin (Gold and Alic, 1993). As mentioned above, $P$. chrysosporium and $T$. versicolor are the most commonly used model organisms in lignin biodegradation studies (Gold and Alic, 1993). They possess enzymes, such as lignin peroxidase (LiP), manganese peroxidase $(\mathrm{MnP})$, and laccase, all involved in lignin degradation. The extracellular enzymatic systems employed are non-specific, and are used in the degradation of several xenobiotics, including pesticides (Bending et al., 2002).

\section{Degradation of pesticides by white-rot fungi.}

Several classes of pesticides as lindane, atrazine, diuron, terbuthylazine, metalaxyl, DDT, gamma-hexachlorocyclohexane (g-HCH), dieldrin, aldrin, heptachlor, chlordane, lindane, mirex, etc. have been degraded at different extent by white-rot fungi (Kennedy et al., 1990; Hickey et al., 1994; Mougin et al., 1994; Singh and Kuhad, 1999; Bending et al., 2002; Quintero et al., 2007). Jauregui et al. (2003) reported that Bjerkandera adusta, Pleurotus ostreatus and $P$. chrysosporium depleted 50 to $96 \%$ of terbufos, azinphosmethyl, phosmet and tribufos after four- day exposure to the pesticides. MCPA and bentazon were degraded by $P$. chrysosporium at $65 \%$ and $75 \%$ respectively in 20 days (Castillo et al., 2001). Rubilar et al (2007) and Tortella et al. (2008) reported that the native Chilean white-rot fungi, A. discolor can degrade and grow in the presence of chlorinated compound as Pentachlorophenol (PCP).

$P$. chrysosporium (Reddy and Gold, 2000) and T. Versicolor (Sedarati et al., 2003) have been the most widely used fungi for PCP degradation. Nevertheless, diverse studies have been performed to evaluate new fungal strains with a high ability for the degradation of recalcitrant organic compounds like chlorophenols (Levin et al., 2004; Rubilar et al., 2007, Tortella et al., 2008). Several fungi, such as Agrocybe semiorbicularis, Auricularia auricula, Coriolus versicolor, Dichomitus squalens, Flammulina velupites, Hypholoma fasciculare, Pleurotus ostreatus, Stereum hirsutum, and A. discolor, have shown their ability to degrade various pesticide groups like phenylamide, triazine, phenylurea, dicarboximide, chlorinated and organophosphorus compounds (Bending et al., 2002). P. chysosporium degraded isoproturon belonging to phenylurea groups (Wirén-Lehr et al., 2001), B. adusta and $A$. discolor Sp4 the pesticide pentachlorophenol (Rubilar et al., 2007), and T. versicolor and Agaricus augustus degraded 2,4,6-tribromophenol (Donoso et al., 2008).

Biodegradation of pentachlorophenol in soil slurry cultures by B. adusta and A. discolor Sp4 was studied by Rubilar et al., 2007. The high degradation rates obtained during the fungal cultures were due to the agitation imposed to maintain the slurry phase, which, in turn, increased the bioavailability of the pollutant to the fungi. Between the two fungal strains, $A$. discolor $\mathrm{Sp} 4$ presented the best results in terms of ligninolytic activity and PCP 
degradation potential. These parameters were increased when a lignocellulosic waste was used as a substrate. However, no correlation between PCP degradation and ligninolytic activity was observed either from the small flask cultures or from the soil slurry system in the stirred tank reactor. The degradation pathway of pentachlorophenol by A. discolor $\mathrm{Sp} 4$ in the soil slurry reactor has been established by Rubilar (2007) and is shown in Figure 2.<smiles>COc1c(Cl)c(Cl)c(Cl)c(Cl)c1Cl</smiles>

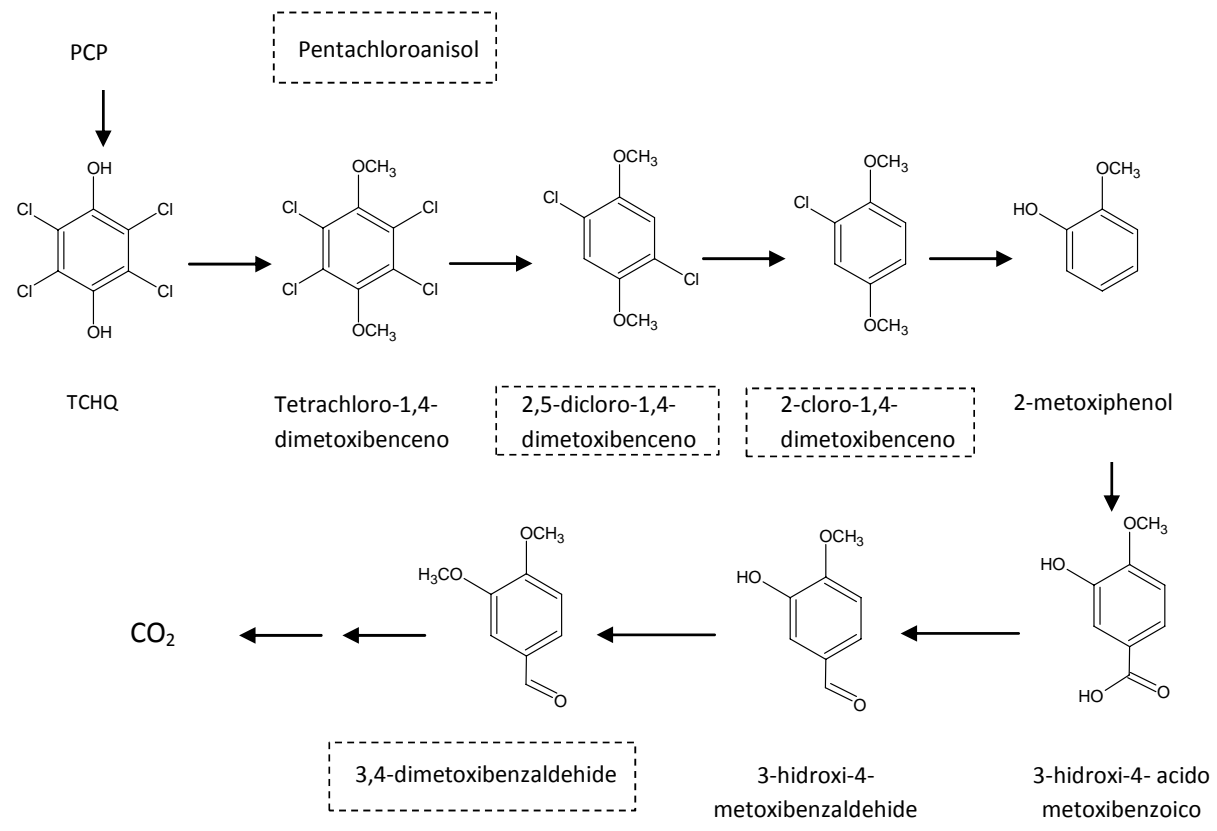

Figure 2. Proposed pathways for the degradation of pentachlorophenol by Anthracophyllum discolor in soil slurry reactor. Framed compounds correspond to those identified by GC-MS (Rubilar, 2007).

The enzymatic characterization of Chilean native wood-rotting fungi for their potential use in the bioremediation of environments polluted with chlorophenols has been studied by Tortella et al. (2008). Eleven strains were selected and showed high concentrations of lignin peroxidase (Lip) and manganese peroxidase (MnP).
A. discolor ( $\mathrm{Sp} 4)$ produced LiP and $\mathrm{MnP}$ at 90.3 and $125.5 \mathrm{U} \mathrm{L}^{-1}$ respectively, compared with the control fungus $P$. chrysosporium CECT-2798 that produced 58.1 and $118.4 \mathrm{U} \mathrm{L}^{-1}$ of $\mathrm{LiP}$ and $\mathrm{MnP}$, respectively. Tolerance tests showed that native Chilean fungi did not present high tolerance to 2,4,6-TCP and PCP, but they 
were quite tolerant to 25 and $50 \mathrm{mg} \mathrm{L}^{-1}$ of 2,4-DCP. However, pre-acclimatization in 2,4-DCP notably improved the growth in medium with 2,4,6-TCP and PCP. PCP in liquid medium was efficiently degraded by the fungi A. discolor, Lenzites betulina (Ru-30) and Galerina patagónica (Sp3), and the highest MnP activity was produced by $A$. discolor (Sp4) $\left(67 \mathrm{U} \mathrm{L}^{-1}\right)$.

\section{TECHNOLOGIES FOR PESTICIDE MITIGATION IN THE ENVIRONMENT}

Several different technologies available for the treatment of pesticidecontaminated sites have been reported (Wait and Thomas, 2003; Aitken and Long, 2004; Chaudhry et al. 2005; DeWilde et al., 2007; Shaalan et al., 2007). These are based on physical, chemical and biological treatments. Ideally, a treatment will result in the destruction of the compound without the generation of intermediates. Some technologies are only capable of relocating or stabilizing a contaminant and do not result in its destruction. In general, it has been observed that these treatments present high removal efficiency; nevertheless, they present diverse costs and variable times of treatment for the removal of these pollutants. No single specific technology may be considered as a panacea for all contaminated site problems. A complete analysis of the site restoration techniques that may be employed in a variety of contaminated site cleanup programs has been reviewed by Khan et al. (2004). An easy-to-use summary of the analysis of the important parameters that will help in the selection and implementation of one or more appropriate technologies in a defined set of sites and contaminant characteristics is also included in the review of Khan et al. (2004).
Bioremediation process can be divided into three phases or levels. First, through natural attenuation, contaminants are reduced by native microorganisms without any human augmentation. Second, biostimulation is employed where nutrients and oxygen are applied to the systems to improve their effectiveness and to accelerate biodegradation. Finally, during bioaugmentation, microorganisms are added to the systems. These supplemental organisms should be more efficient than native flora to degrade the target contaminant (Salinas-Martínez et al., 2008). Inside this context, several methodologies for removal of toxic compounds in wastewater through biodegradation process have been evaluated, among some the use of slurry batch bioreactor with soil (Quintero et al., 2007; Rubilar et al, 2007), organic waste addition (Aslan and Türkman, 2005; Cea et al., 2007b; Trejo-Hernández et al., 2007; Seo et al., 2007), soil-organic waste mixture (Vischetti et al., 2004), and microorganisms inoculation in organic supports (Bending et al., 2002; Quintero et al., 2007; Wu and $\mathrm{Yu}, 2008)$.

The current knowledge on mitigation strategies to reduce pesticide inputs into surface water and groundwater, and their effectiveness when applied in practice has been reviewed by Reichenberger et al. (2007). In the review, the mitigation measures identified in the literature are evaluated with respect to their practicability, and those measures considered both effective and feasible are recommended for implementing at the farm and catchment scale. On the other hand, Castillo et al. (2008) have presented the state of the art of biobeds, a low-cost technology for point source contamination for pesticide mitigation, and similar systems in Sweden and worldwide and identified future research needs. Factors affecting the efficiency of biobeds in 
terms of degradation and retention of pesticides are discussed, with particular emphasis on the microbial processes involved.

\section{Pesticides degradation in biobeds}

Biobeds are a biological system originated in Sweden as a response to the need for a simple and effective system to minimize environmental contamination from pesticide manipulation, especially when filling the spraying equipment, a typical point source of contamination (Figure 3) (Tortensson and Castillo, 1997; Castillo et al., 2008). In Sweden and in other countries of Europe, great quantities of biobeds are functioning in farms and they have shown to be efficient at reducing pesticide water-body contamination (Castillo et al., 2008; Vischetti et al., 2007). Biobeds are based on the adsorption and degradation potential of organic biomixtures composed of top soil, peat, and straw and covered with grass (Tortensson and Castillo, 1997). Biobeds are a low-cost alternative for treating pesticide waste and washings, providing a matrix to absorb the pesticides and facilitate their biodegradation. Straw stimulates growth of ligninolytic microorganisms and the production of extracellular ligninolytic enzymes as peroxidases and phenoloxidases. The peat contributes to sorption capacity, moisture control and also abiotic degradation of pesticides and also decreases $\mathrm{pH}$ of the biomixture, which is favorable for fungi and their pesticide-degrading enzymes (Castillo et al., 2001; Torstensson and Castillo, 1997). Soil enhances the sorption capacity in the biobed. It should have humus and clay content to promote microbial activity. Moreover, it is also an important source of pesticide-degrading bacteria or Actinomycetes that can act synergistically with the fungi. Chilean Andisol is an effective support for this system due to its high organic matter content with great affinity for pollutants due to the presence of humic and fulvic acids and reactive clays like $\mathrm{Al}$ and $\mathrm{Fe}$ hydroxide groups (Navia et al., 2005).

Several studies have demonstrated that biobeds can effectively retain and degrade pesticides (Torstensson and Castillo, 1997; Castillo et al., 2001; Fogg et al., 2003 a,b; Fogg et al., 2004 a,b; Vischetti et al., 2004; Castillo and Torstensson, 2007; Vischetti et al., 2008).

Studies with mecoprop and isoproturon have shown than these pesticides can be degraded in biobeds (Henriksen et al., 2003). Niels et al. (2006) evaluated the degradation and leaching of 21 pesticides. They determined than no traces of 10 out of 21 applied pesticides were detected in the percolate. Fogg et al. (2003a) evaluated the ability of biobeds to degrade pesticide mixtures (isoproturon and chlorothalonil) and the concentration effect. They found that with the exception of isoproturon at concentration above $11 \mathrm{mg} \mathrm{kg}{ }^{-1}$, degradation was quicker in biomix than in topsoil. The degradation of either isoproturon or chlorothalonil was unaffected by the presence of the other pesticide. Fogg et al. (2003b) determined if biobeds can degrade complex pesticides mixtures when applied repeatedly. They reported that degradation was significantly quicker in biomix than in topsoil; however, it decreased with each additional treatment. Fogg et al. (2004a) studied the degradation and leaching potential of pesticides at the semi-field scale, in a lined biobed and unlined biobed system. They reported that only the most mobile pesticides $\left(\mathrm{K}_{\mathrm{oc}}<100\right)$ leached when unlined biobed was used, and for these $>99 \%$ was removed by the system, with a significant proportion degraded within 9 months.

Laboratory-based studies showed that mixtures of soil-organic waste may be able to degrade high concentrations and complex mixtures of pesticides (Fogg et 


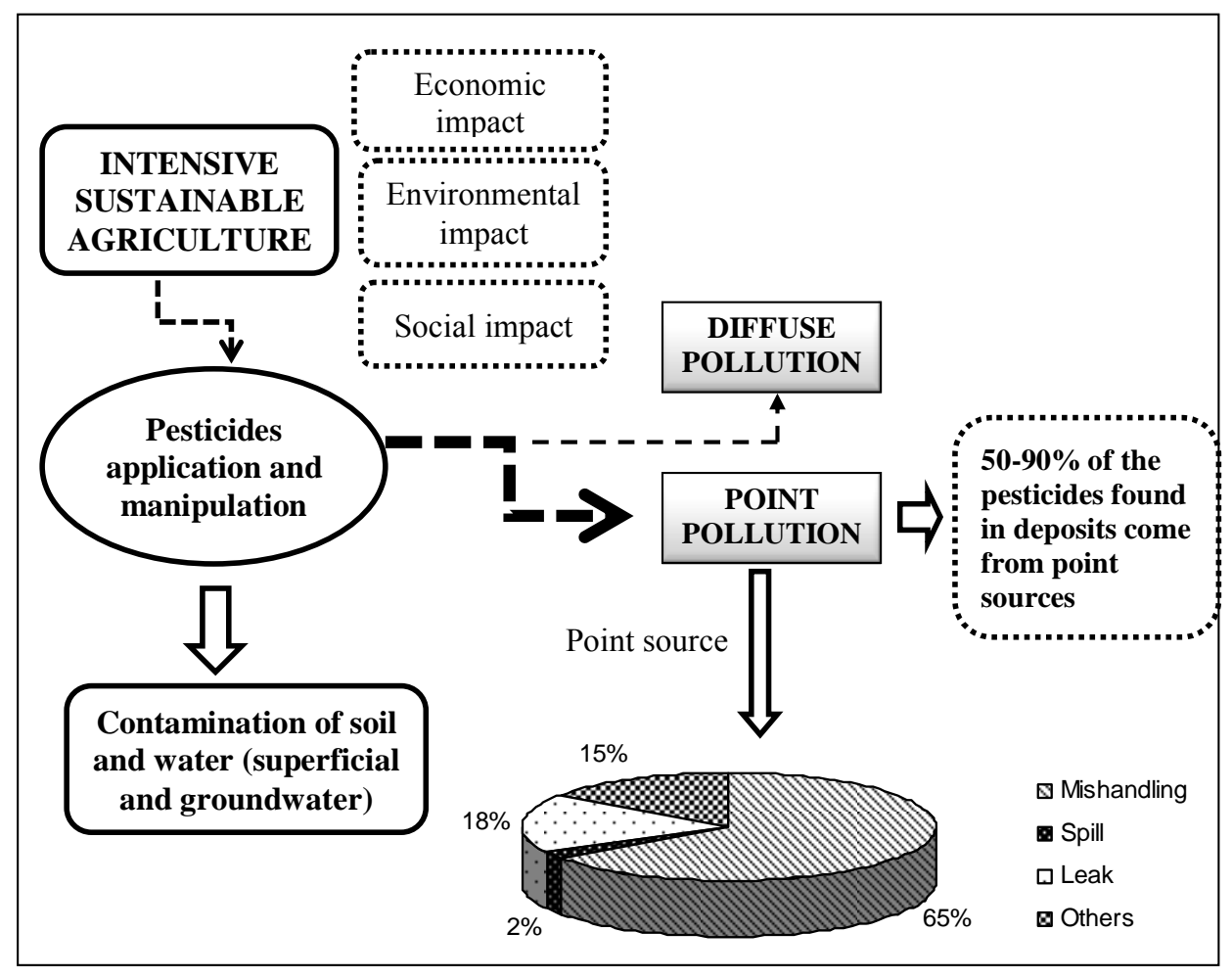

Figura 3. Diagram of effects of contamination associated with pesticides application and manipulation and, distribution (\%) of the point source contamination during handling.

al., 2004b). However, factors such as composition, flow, concentration of influent and bed depth are crucial parameters for the fixed bed column operation (Wu and $\mathrm{Yu}, 2008)$. Consequently it is important to establish the proportion of materials in the column mixture giving the highest degradation and sorption efficiency. Castillo and Tortensson, (2007) observed that a straw: peat: soil ratio of $50: 25: 25 \% \mathrm{v} / \mathrm{v}$ is recommended for the organic mixture composition, because such mixture favors a low $\mathrm{pH}$, convenient for lignin-degrading fungi and phenoloxidase production and activity.
Vischetti et al. (2004) compared the behavior of chlorpyrifos in two biobed systems: a Swedish biobed and a modified Italian system of biobeds. They reported that chlorpyrifos half-lives were similar in both evaluated biomixtures, but the microbial biomass content was reduced by 25 and $50 \%$ with 10 and $50 \mathrm{mg} \mathrm{kg}^{-1}$ of chlorpyrifos in the Italian biomix, respectively. Coppola et al. (2007) and Vischetti et al. (2007) studied the biodegradation of chlorpyrifos in biobeds system adapted to Italian conditions. They found that the Italian biomix showed several differences, compared with 
Swedish biomix in the chlorpyrifos degradation.

The effect of initial concentration, coapplication and repeated applications on chlorpyrifos and metalaxyl degradation were studied in a biobed mixture by Vischetti et al. (2008). The authors concluded that biomix in biobed degraded both pesticides relatively fast and had a microbial community that is varied enough to allow selection of those microorganisms able to degrade both pesticides.

Several pesticides were degraded in biobeds inoculated with white-rot fungi (Bending et al., 2002). The authors determined that some pesticides were degraded by about $86 \%$ in biobeds; however, pesticides as chlorpyrifos and terbuthylazine were less degraded. WirénLehr et al. (2001) studied the degradation of isoproturon in biobeds with and without inoculation with white-rot fungus Phanerochaete chrysosporium. They determined that a strong decrease in the concentration of isoproturon was observed in non-inoculated biobeds. Total extractable isoproturon decreased by $76 \%$ after 100 days. However, the decrease was even larger in biobeds inoculated with the white rot fungus $P$. chrysosporium. After 28 days, total extractable isoproturon decreased by $78 \%$, and after 100 days $>99$ $\%$ had disappeared in the biobeds.

Although, it has been shown that biobeds can be used to degrade pesticides, there is no information in the literature about their improvement through strategies such as biostimulation.

Tortella, et al. (2009) studied whether biomix of biobed systems with allophanic top soil (Andisol) from southern Chile can degrade effectively the organophosphorous insecticide chlorpyrifos. The results of this study showed that preincubation time of biomix with allophanic soil between 15-30 days had no major effect on the chlorpyrifos degradation. High chlorpyrifos concentration can be degraded in biobed, and the metabolite 3,5,6-trichloro-2-pyridinol (TCP) was formed, but it also can be degraded by this system. Pentachlorophenol (PCP) degradation in two biological systems (biobed and fixed-bed column) has been studied by Diez and Tortella (2008). Both systems were inoculated with $A$. discolor $\mathrm{Sp} 4$ immobilized in lignocellulosic material. In the biobed system, degradation of PCP (after three successive applications of $100 \mathrm{mg} \mathrm{kg} \mathrm{kg}^{-1}$ each) occurred efficiently over the whole incubation period. However, it was significantly quicker in biobed amended with the fungus compared with noninoculated biobed. A fraction of the initial PCP concentration was adsorbed (aprox. $40 \%$ ) in each application by the biobed matrix. The manganese peroxidase activity was the highest in inoculated biobeds, and the laccase activity was the highest in control biobed. In fixed-bed column, PCP adsorption onto the soil was high in the initial step (12 h) and then PCP was efficiently degraded until saturation of the columns (day 16). The highest degradation of PCP coincides with the $\mathrm{MnP}$ production, showing that $A$. discolor $\mathrm{Sp} 4$ increased degradation of PCP.

\section{CONCLUDING REMARKS}

Some of the synthetic chemicals are extremely resistant to biodegradation by native flora compared with the naturally occurring organic compounds that are readily degraded upon introduction into the environment. The dissipation of organic recalcitrant pollutants in soil environment is influenced by both adsorption and biological processes. Depending on the soil properties, the biological decomposition of pesticides is the most important and effective way to remove these compounds from this 
environment. White-rot fungi can degrade pesticides effectively with advantages associated with their ligninolytic enzymatic system. These fungi play an important role in the dissipation of pesticides in biobeds, an effective system to minimize environmental contamination from pesticide manipulation. However, further studies are needed to evaluate alternatives of bioaugmentation of biobed systems with inoculum of native fungi or consortium of fungi and Actinomycetes, as well as new technologies to protect these inocula of autochthonous microflora depletion must be developed.

\section{ACKNOWLEDGEMENTS}

This review was supported by FONDECYT 1090678 project. The author is grateful to Dr. Gonzalo Tortella, Dr. Olga Rubilar, Dr. Gabriela Briceño, Dr. Mara Cea, Dr. Francisca Acevedo, and Mariela Bustamante for their collaboration.

\section{REFERENCES}

Acevedo, F., Pizzul, L., Castillo, MdP., González, M.E., Cea, M., Gianfreda, L., Diez, M.C. 2010. Degradation of polycyclic aromatic hydrocarbons by free and nanoclayimmobilized manganese peroxidase from Anthracophyllum discolor. Chemosphere 80(3), 271-278.

Aitken, M., Long, T.C. 2004. Biotransformation, biodegradation and bioremediation of polycyclic aromatic hydrocarbons, in soil biology, Vol 2: Biodegradation and bioremediation (Eds: A. Singh, O.P Ward), Springer verlag, Berlin, Heidelberg, 83-124.

Alister, C., Rojas, S., Gómez, P., Kogan, M. 2008. Dissipation and movement of flumioxazin in soil at four field sites in Chile. Pest. Manag. Sci. 64, 579-583.
Arias-Estévez, M., López-Periago, E., Martínez-Carballo E., Simal-Gándara, J., Mejuto, J.C., García-Río, L. 2008. The mobility and degradation of pesticides in soils and the pollution of groundwater resources. Agr. Ecosyst. Environ. 123, 247-260.

Aslan, S., Türkman, A. 2005. Combined biological removal of nitrate and pesticides using wheat straw as substrates. Process Biochem. 40, 935-943.

Awasthi, M., Prakash N.B. 1997. Persistence of Chlorpyrifos in Soils under Different Moisture Regimes. Pestic. Sci. 50 (1), 1-4.

Baez, M., Rodriguez, M., Lastra, O., Peña, A., De La Colina, C., Sanchez Rasero, F., 1996. Residuos de plaguicidas en aguas superficiales de la V región de Chile. Estudio prospectivo. Bol. Soc. Chil. Quim. 41, 271-276.

Barajas-Aceves, M., Hassan, M., Tinoco, R., Vazquez-Duhalt, R. 2002. Effect of pollutants on the ergosterol content as indicator of fungal biomass. J. Microbiol. Meth. 50, 227-236.

Barcelo, D. 1991. Occurrence, handling and chromatographic determination of pesticides in the aquatic environment. Analyst 116, 681689.

Barra, R., Pozo, K., Urrutia, R. 2001. Plaguicidas organoclorados persistentes en sedimentos de tres lagos costeros y un lago andino de chile central. Bol. Soc. Chil. Quím. 46 (2), 149-159.

Barriuso E., Laird, D.A., Koskinen, W.C., Dowdy, R.H. 1994. Atrazine desorption from smectites. Soil Sci. Soc. Am. J. 58, 1632-1638.

Barriuso, E., Calvet, R. 1992. Soil type and herbicides adsorption. Int. J. Environ. Anal. Chem. 46, 117-128.

Bayley, G.W., White, J.L., 1970. Factors influencing the adsorption, desorption, and movement of pesticides in soils. Residue Rev. $32,29-92$.

Bending, G., Friloux, D.M., Walker A. 2002.

Degradation of contrasting pesticides by white rot fungi and its relationship with ligninolytic potential. FEMS Microbiol. Lett. 212, 59-63. 
Benimeli, C.S., Fuentes, M.S., Abate, C.M., Amoroso, M.J. 2008. Bioremediation of lindane-contaminated soil by Streptomyces sp. M7 and its effects on Zea mays growth. Int. Biodeter. Biodegr. 61(3), 233-239.

Benimeli, C.S., Amoroso, M.J., Chaile, A.P., Castro, G.R. 2003. Isolation of four aquatic streptomycetes strains capable of growth on organochlorine pesticides. Bioresource Technol. 89(2), 133-138.

Bezama, A., Navia, R., Mendoza, G., Barra, R. 2008. Remediation technologies for organochlorine-contaminated sites in developing countries. Rev. Environ. Contam. Toxicol. 193, 1-29.

Bhadbhade, B.J., Sarnaik, S.S., Kanekar, P.P. 2002. Bioremediation of an industrial effluent containing monocrotophos. Curr. Microbiol. 45, 346-349.

Boivin, A., Amellal, S., Schiavon, M., van Genuchten, M.T. 2005. 2,4-D sorption and degradation dynamics in three agricultural soils. Environ. Pollut. 138 (1), 92-99.

Briceño, G., Palma, G., Durán, N. 2007. Influence of organic amendment on the biodegradation and movement of pesticides Crit. Rev. Environ. Sci. Tech. 37, 233-271.

Bromilow, R.H., Evans, A.A., Nicholls, P.H., 1999. Factors affecting degradation rates of five triazole fungicides in two soil types: 1 . Laboratory incubations. Pestic. Sci. 55, 1129 1134.

Brücher J., Bergström, L. 1997. Temperature dependence of linuron sorption to three different agricultural soils. J. Environ. Qual. 26, 13271335.

Castillo M.P., Torstensson L, Stenstrom J. 2008. Biobeds for environmental protection from pesticide use-A review. J. Agric. Food. Chem. 56, 6206-6219.

Castillo, M.P., Tortensson, L. 2007. Effect of biobed composition, moisture, and temperature on the degradation of pesticides. J. Agric Food Chem. 55, 5725-5733.

Castillo, M.P., Andersson, A., Ander, P., Stenstron, J., Torstensson, L. 2001 Establishment of the white rot fungus Phanerochaete chrysosporium on unsterile straw of solid subtrate fermentation systems intended for degradation of pesticides. World J. Microbiol. Biotechnol. 17, 627-633.

Cea, M., Seaman, J.C., Jara, A., Fuentes, B., Mora, M.L., Diez, M.C. 2007a. Adsorption Behavior of 2,4-Dichlorophenol and Pentachlorophenol in an Allophanic Soil. Chemosphere 67, 1354-1360.

Cea, M. Rubilar, O., Tortella, G., Diez, M.C. 2007b. Utilization of straw as substrate to enhance the ligninolytic and degradative activity of Anthracopyllum discolor and indigenous microrganisms in a chilean soil contaminated with PCP. Third International Conference, Enzymes in the Environment. 1519 de Julio de 2007, Viterbo, Italy.

Cea, M. 2006. Estudio de la retención de compuestos organoclorados de bajo peso molecular en suelo alofánico: mecanismos físico químicos de interacción. Doctoral thesis, La Fontera University, Chile, 105 p. (http://www.ufro.cl/rrnn).

Cea, M., Seaman, J.C., Jara, A., Mora, M.L. Diez, M.C. 2005. Describing chlorophenol sorption on variable-charge soil using the triple-layer model. J. Colloid Interf. Sci. 292 (1), 171-178.

Cervelli, S., Nannipieri, P., Sequi, P., 1978. Interaction between agrochemicals and soil enzymes. In: Burns, R.G. (ed.). Soil Enzymes. Academic Press, London, pp. 251-293.

Chaudhry, Q., Blom-Zandstra, M., Gupta, S., Joner, E. 2005. Utilising the synergy between plants and rhizosphere microorganisms to enhance breakdown of organic pollutants in the environment. Environ. Sci. Pollut. Res. 12(1), 34-48.

Chirnside, A., Ritter, W., Radosevich, M. 2007. Isolation of a selected microbial consortium from a pesticide-contaminated mix-load site soil capable of degrading the herbicides atrazine and alachlor. Soil Biol. Biochem. 39, 3056-3065.

Chu, X., Fang, H., Pan, X., Wang, X., Shan, M., Feng, B., Yu, Y. 2008. Degradation of chlorpyrifos alone and in combination with chlorothalonil and their effects on soil microbial populations. J. Environ. Sci. 20, 464-469. 
Chu, W., Chan, K.H. 2003. The mechanism of the surfactant-aided soil washing system for hydrophobic and partial hydrophobic organics. Sci. Total Environ. 307, 83-92.

Clausen, L., Fabricius, I., 2002. Atrazine, isoproturon, mecoprop, 2,4-D, and bentazone adsorption onto iron oxides. J. Environ. Qual. $30(3), 858-869$.

Cooman, K. Debels, P. Gajardo, M. Urrutia, R., Barra, R. 2005. Use of Daphnia spp. for the ecotoxicological assessment of water quality in an agricultural watershed in south-central Chile. Arch. Environ. Contam. Toxicol. 48, 191-200.

Coppola, L., Castillo, M.d.P., Monaci, E., Vischetti, C. 2007. Adaptation of the biobed composition for chlorpyrifos degradation to southern Europe conditions. J. Agr. Food Chem. 55, 396-401.

D’Annibale, A., Ricci, M., Leonardi, V., Quaratino, D., Mincione, E., Petruccioli, M. 2005. Degradation of aromatic hydrocarbons by white-rot fungi in a historically contaminated soil. Biotechnol. Bioeng. 90(6), 723-731.

De Schrijver, A., De Mot, R. 1999 Degradation of pesticides by actinomycetes, Crit. Rev. Microbiol. 25, 85-119.

De Wilde,T., Spanoghe, P., Debaer, C., Ryckeboer, J. Springael, D., Jaeken, P. 2007. Overview of on-farm bioremediation systems to reduce the occurrence of point source contamination. Pest Manag. Sci. 63, 111-128.

DGA (Dirección General de Aguas) 2004 Diagnóstico y clasificación de los cursos de agua según objetivos de calidad: cuenca del río Limarí. Informe técnico. $231 \mathrm{p}$. (http://www.dga.cl/index.php)

Diez, M.C., Tortella, G.R. 2008 Pentachlorophenol degradation in two biological systems: biobed and fixed-bed column, inoculated with the fungus Anthracophyllum discolor. ISMOM November 24-27, Pucón, Chile.

Diez, M.C, Quiroz, A., Ureta-Zañartu, S., Vidal, G., Mora, M.L., Gallardo, F., R. Navia. 2005. Soil retention capacity of phenol from biologically pre-treatment kraft mill wastewater. Water Air Soil Poll. 163, 325-339.

Diez, M.C., Mora, M.L., Videla, S. 1999 Adsorption of phenol and color from BKME using synthetic allophanic compounds. Water Res. 33(1), 125-130.

DiVincenzo, J., Sparks, D.L. 2001. Sorption of the neutral and charges forms of pentachlorophenol on soil: evidence for different mechanisms. Arch. Environ. Contam. Toxicol. 40, 445-450.

Donoso, C., Becerra, J., Martínez, M. Garrido, N., Silva, M. 2008. Degradative ability of 2,4,6-tribromophenol by saprophytic fungi Trametes versicolor and Agaricus augustus isolated from Chilean forestry. World J. Microb. Biot. 24, 961-968

Eizuka, E., Ito, A., Chida, T. 2003. Degradation of ipconazole by microorganisms isolated from paddy soil, J. Pestic. Sci. 28 p. 200.

El-Nahhal, Y., Nir, S., Polubesova, T., Margulies, L., Rubin, B., 1997. Organo-clay formulations of alachlor: reduced leaching and improved efficacy. Proc. Brighton Crop Prot. Conf. Weeds 1, 21-26.

El-Nahhal, T., Undabeytia, T., Polubesova, Y.D., Mishael, S., Nir, B., Rubin. 2001 Organoclay formulations of pesticides: reduced leaching and photodegradation, Appl. Clay Sci. $18,309-326$.

Evans, C.S., Dutton M.V., Guillen, F., Veness, R.G. 1994. Enzymes and small molecular-mass agents involved with lignocellulose degradation. FEMS Microbiol. Rev. 13, 235-240.

Fatoki, O.S., Awofolu, O.R. 2005. Levels of organochlorine pesticide residues in marine, surface, ground and drinking waters from the Eastern Cape Province of South Africa. J. Environ. Sci. Heal.B. 39, 101-114.

Focardi, S., Fossi, C., Leonzio, C., Corsolini, S., Parra, O. 1996. Persistent organochlorine residues in fish and water birds from the Biobio river, Chile. Environ. Monit. Assess. 43, 7392. 
Fogg, P., Boxall, A.B.A., Walker, A. 2003a Degradation of pesticides in biobeds: The effect of concentration and pesticide mixtures. J. Agr. Food Chem. 51, 5344-5349.

Fogg, P., Boxall, A.B.A., Walker, A., Jukes, A.A. 2003b. Pesticide degradation in a "biobed" composting substrate. Pest Manag. Sci. 59, 527-537.

Fogg, P., Boxall, A.B.A., Walker, A., Jukes, A. 2004a. Degradation and leaching potential of pesticides in biobed systems. Pest Manag. Sci. 60, 645-654.

Fogg, P., Boxall, A.B.A., Walker, A., Jukes, A. 2004b. Leaching of pesticides from biobeds: Effect of biobed depth and water loading. J. Agr. Food Chem. 52, 6217-6227.

Gevao, B., Semple, K.T., and Jones, K.C. 2000. Bound pesticide residues in soil: A review. Environ. Pollut. 108(1), 3-14.

Gianfreda, L., Rao M. 2008. Interactions Between xenobiotics and Microbial and Enzymatic Soil Activity. Crit. Rev. Env. Sci. Tec. 38, 269-310.

Gianfreda, L., Mora M.L., Diez, M.C. 2006. Biological agents involved in the bioremediation of soils contaminated with persistent organic compounds. In: Biorremediación de suelos contaminados con compuestos orgánicos persistentes (COPs). Editores: R. Navia, M. Seeger. Ediciones Universidad de La Frontera. ISBN 956-2361705-5, pag. 45-86.

Gianfreda L., Rao, M. 2004. Potential of extra cellular enzymes in remediation of polluted soils: a review. Enzyme Microb. Tech. 35, 339-354.

Gilliom, RJ. 2007. Pesticides in U.S. streams and groundwater. Environ Sci Technol 41, 3408-3414.

Gold, M., Alic, M. 1993. Molecular biology of the lignin-degrading basidiomycete Phanerochaete chrysosporium. Microbiol. Rev. 57, 605-622.

Goss, M.J., Barry, D., Rudolph, D. 1998. Contamination in Ontario farmstead domestic wells and its association with agriculture: results from drinking water wells. J. Contam. Hydrol. 32, 267-293.
Guerin, T. 1999. Natural attenuation of a low mobility chlorinated insecticide in low-level and high-level contaminated soil: A feasibility study. Remediation J. 9 (4), 51-63

Hallberg, G.R. 1989. Pesticide pollution of groundwater in the humid United States. Agr. Ecosyst. Environ. 26, 299-367.

Hart. M.R., Brookes, P.C. 1996. Soil microbial biomass and mineralization of soil organic matter after 19 years of cumulative field applications of pesticides, Soil Biol. Biochem. 28, 1641-1649.

Henriksen, V.V., Helweg, A., Spliid, N.H., Felding, G., Stenvang, L. 2003. Capacity of model biobeds to retain and degrade mecoprop and isoproturon. Pestic. Manag. Sci. 59, 10761082.

Henríquez, M., Becerra, J., Barra, R. and Rojas, J. 2006 . Hydrocarbons and organochlorine pesticides in soils of the urban ecosystem of chillán and chillán viejo, Chile. J. Chil. Chem. Soc. 51(3), 938-944.

Hernández, M., Morgante, V., Avila, M., Villalobos, P., Miralles, P., Gonzalez, M. Seegers, M. 2008. Novel s-triazine-degrading bacteria isolated from agricultural soils of central Chile for herbicide bioremediation Electron. J. Biotechn. 11(5), 1-6

Hickey, W.J., Fuster, D.J., Lamar, R.T. 1994. Transformation of atrazine in soil by Phanerochaete chrysosporium Soil Biol. Biochem. 26, 1665È71.

Jauregui, J., Valderrama, B., Albores, A., Vazquez-Duhalt, R. 2003. Microsomal transformation of organophosphorus pesticides by white rot fungi. Biodegradation 14, 397406.

Khan, F., Husain, T., Hejazi, R. 2004. An overview and analysis of site remediation technologies. J. Environ. Manag. 71, 95-122.

\section{Karasali H. Hourdakis A., Anagnostopoulos H. 2002. Pesticide residues in thermal mineral water in Greece. J. Environ. Sci. Heal B. 37(5), 465-474.}

Kennedy, D.W., Aust, S.D., Bumpus, J.A. 1990. Comparative biodegradation of alkyl halide insecticides by the white rot fungus 
Phanerochaete chrysosporium (BKM-F1767). Appl. Environ. Microbiol. 56, $2347 \mathrm{E} 53$.

Kookana, R.S., Rogers, S.L. 1995. Effects of pulp mill effluent disposal on soil. Rev. Environ. Contam. Toxicol. 142, 13-64.

Kremer, R.J, Means, N.E. 2009. Glyphosate and glyphosate-resistant crop interactions with rhizosphere microorganisms Europ. J. Agron. $3,153-161$.

Laabs, V., Amelung, W., Pinto, A., Wantzen, M.J., da Silva, C., Zech, W. 2002. Pesticides in surface water, sediment, and rainfall of the northeastern Pantanal basin, Brazil. J. Environ. Qual. 31, 1636-1648.

Laird, D.A. Yen, P.Y. Koskinen, W.C. Steinheimer T.R., Dowdy, R.H. 1994. Sorption of atrazine on soil clay components, Environ. Sci. Technol. 28, 1054-1061.

Larkin, M., Kulakov, L., Allen, C. 2005. Biodegradation and Rhodococcus-masters of catabolic versatility. Curr. Opin. Biotech. 16, 282-290.

Leistra, M., Boesten, J.J.T.I. 1989. Pesticide contamination of groundwater in Western Europe. Agric. Ecosyst. Environ. (26), 369389.

Levin, L., Papinutti, L., Forchiassin, F. 2004. Evaluation of Argentinean white rots fungi for their ability to produce ligninmodifyng enzymes and decolorize industrial dyes. Bioresource Technol. 2, 169-176.

Maanen, J.M.S., de Vaan, M.A.J., Veldstra, A.W.F., Hendrix, W.P.A. 2001. Pesticides and nitrate in groundwater and rainwater in the province of Limburg in the Netherlands. Environ. Monit. Assess. 72, 95-114.

Madhun, Y.A., Freed, V.H. 1990. Impact of pesticides on the environment. In: Pesticides in

the soil environment; SSSA Book Series, no. 2, Soil Science Society of America pp. 429 466.

Maloschik, E., Ernst, A., Hegedüs, G., Darvas, B, Székács, A. 2007. Monitoring water-polluting pesticides in Hungary. Microchem. J. 85, 88-97.
Meade, T., D’Angelo, E.M. 2005. $\left[{ }^{14} \mathrm{C}\right]$ Pentachlorophenol mineralization in the rice rhizosphere with established oxidized and reduced soil layers. Chemosphere 61, 48-55.

Mercadier, C., Vega, D., Bastide, J. 1997. Iprodione degradation by isolated soil microorganisms. FEMS Microbiol. Ecol. 23, 207-215.

Mougin, C., Laugero, C., Asther, M., Dubroca, J., Frasse, P., Asther, M. 1994. Biotransformation of the herbicide atrazine by the white rot fungus Phanerochaete chrysosporium. Appl. Environ. Microbiol. 60, 705-708.

Navia, R., Fuentes, B., Lorber, K., Mora, M.L., Diez, M.C. 2005. In-series columns adsorption performance of krakt mill wastewater pollutants onto volcanic soil. Chemosphere 60, 870-878.

Niels, H., Helweg, A., Heinrichson, K. 2006. Leaching and degradation of 21 pesticides in full-scale model biobeds. Chemosphere 65, 2223-2232.

Palma, G., Sanchez, A., Olave, Y., Encina, F., Palma, R., Barra, R. 2004. Pesticides levels in surface waters in agricultural-forestry basin in southern Chile. Chemosphere 57, 763 770 .

Paraíba, L.C., Cerdeira, A.L., Da Silva, E.F., Martins, J.S. Coutinho, H.L.A. 2003. Evaluation of soil temperature effect on herbicide leaching potential into groundwater in the brazilian cerrado. Chemosphere 53(9), 1087-1095.

Paraíba, L.C., Spadotto, C.A. 2002. Soil temperature effect in calculating attenuation and retardation factors. Chemosphere 48, 905-912.

Pesce S., Wunderlin, D. 2004 Biodegradation of lindane by a native bacterial consortium isolated from contaminated river sediment. Int. Biodeter. Biodegr. 54, 255260.

Pizzul, L., Castillo, M.P., Stenström, J. 2007. Effect of rapeseed oil on the degradation of polyclyclic aromatic hydrocarbons in soils by Rhodococcus wratislaviensis. Int. Biodeter. Biodegr. 59, 111-118. 
Planas, C. Caixach, J. Santos, F.J. Rivera, J. 1997. Occurrence of pesticides in Spanish surface waters. Analysis by high-resolution gas chromatography coupled to mass spectrometry, Chemosphere 34, 2393-2406

Pointing, S. B. 2001. Feasibility of bioremediation by white rot fungi. Appl. Microbiol. Biot. 57, 20-33.

Quintero, JC., Lu-Chau,T., Moreira, M.T Feijoo, G., Lema, JM. 2007. Bioremediation of $\mathrm{HCH}$ present in soil by the white-rot fungus Bjerkandera adusta in a slurry batch bioreactor. Int. Biodeter. Biodegr. 60, 319 326.

Racke, K.D., Coats, J.R., Titus, K.R. 1988. Degradation of chlorpyrifos and its hydrolysis products, 3,5,6-trichloro-2-pyridinol, insoil . J. Environ. Sci.Heal. B. 23, 527- 539.

Rama K., Ligy P. 2008. Adsorption and desorption characteristics of lindane, carbofuran and methyl parathion on various Indian soils. J. Hazard. Mater. 160(2-3), 559-567.

Raymond, J. Rogers, T., Shonnard, D., Kline, A. 2001. A review of structure-based biodegradation estimation methods, J. Hazard. Mater. 84, 189-215.

Reddy, G.V.B., Gold, M.H. 2000. Degradation of pentachlorophenol by Phanerochaete chrysosporium: intermediates and reactions involved. Microbiology +146 , 405-413.

Reichenberger, S., Bach, M., Skitschak, A., Frede, H.G. 2007. Mitigation strategies toreduce pesticide imputs into ground-and surface-water and their effectiveness: a review. Sci. Total Environ. 384, 1-35.

Rochkind-Dubinsky, M.L., Sayler, G.S., Blackburn, J.W. 1987. Microbiological decomposition of chlorinated aromatic compounds. New York: Marcel Dekker. Inc. $1-58$

Rubilar, O., Feijoo, G., Diez, M.C., LuChau, T.A., Moreira, M.T. Lema, J.M. 2007. Biodegradation of pentachlorophenol in soil slurry cultures by Bjerkandera adusta and Anthracophyllum discolor. Indust. Engin. Chem. Res. 46, 744-6751.
Rubilar,O. Diez, M.C., Gianfreda, L. 2008. Transformation of chlorinated phenolic compounds by white rot fungi. Crit. Rev. Environ. Sci. Tech. 38, 227-268.

Rubilar, O. 2007. Biorremediación de suelos contaminados con pentaclorofenol (PCF) por hongos de pudrición blanca. Doctoral thesis, La Fontera University, Chile, 133 p. (http://www.ufro.cl/rrnn).

Salinas-Martínez, A., de los SantosCórdova, M., Soto-Cruz, O., Delgado, E., Pérez-Andrade, H., Háuad-Marroquín, L., Medrano-Roldán, H. 2008. Development of a bioremediation process by biostimulation of native microbial consortium through the heap leaching technique. J. Environ. Manage. 88, 115-119.

Schipper, P.N.M., Vissers M.J.M., van der Linden, A.M.A. 2008. Pesticides in groundwater and drinking water wells: overview of the situation in the Netherlands. Water Sci. Technol. 57, 1277-1286.

Sedarati, M.R., Keshavarz, T., Leontievsky, A.A., Evans, C.S. 2003. Transformation of high concentrations of chlorophenols by the white-rot basidiomycete Trametes versicolor immobilized on nylon mesh, Electron. J. Biotechnol. 6,104-114.

Semple, K.T., Morris, W.J., Paton, G.I. 2003. Bioavailability of hydrophobic organic contaminants in soils: fundamental concepts and techniques for analysis. Eur. J. Soil Sci., 54, 809-818.

Senesi, N., 1992. Binding mechanisms of pesticides to soil humic substances. Sci. Total Environ. 123/124, 63-76.

Seo, Y., Jang, A., Bishop, P. 2007. Organic mulch biowall for PAH contaminated groundwater remediation. Eur. J. Soil Biol. 43, 304-309.

Servicio Agrícola y Ganadero (SAG). 2006. Declaración de ventas de plaguicidas año 2004. Subdepartamento de plaguicidas y fertilizantes. División de protección agrícola 140 pp. (www.sag.gob.cl).

Shaalan, H.F., Ghaly, M.Y, Farah, J. 2007.

Techno economic evaluation for the treatment 
of pesticide industry effluents using membrane schemes. Desalinization 204, 265,276.

Shawhney, B.L., Brown, K. 1989. Reactions and movement of organic chemicals in soils. Soil Sci. Soc. Am. Inc. Madison, WI, USA, $474 \mathrm{pp}$.

Singh, N., Megharaj, M., Kookana, R., Naidu, R., Sethunathan, N. 2004. Atrazine and simazine degradation in Pennisetum rhizosphere. Chemosphere. 56, 257-263.

Singh S.B., Lal, S.P., Pant, S., Kulshrestha, G. 2008. Degradation of atrazine by an acclimatized soil fungal isolate. J. Environ. Sci. Heal. B. 43(1), 27-33.

Singh, B.K., Kuhad, R.C. 1999. Biodegradation of lindane (yhexachlorocyclohexane) by the white rot fungus Trametes hirsutus. Lett. Appl. Microbiol. 28, 238-241.

Strong, L.C., Pedersen, C., Sadowsky, M.J., Wackett, L.P. 2002. Arthrobacter aurescens TC1 metabolizes diverse s-triazine ring compounds Appl. Environ. Microbiol. 68, 5973-5980.

Taylor, A.W., Spencer, W.F., 1990 Volatilization and vapor transport processes. In: Cheng, H.H. (Ed.), Pesticides in the Soil Environment Processes, Impacts, and Modeling. Soil Sci. Soc. Am. Inc., Madison, WI, pp. 214-269.

Teixeira, H., Proença, P., Alvarenga, M., Oliveira, M., Marques, E.P., Vieira, D.N. 2004. Pesticide intoxications in the Centre of Portugal: three years analysis. Forest Sci. Int 16;143(2-3), 199-204.

Torstensson, L., Castillo, M.P. 1997. Use of biobeds in Sweden to minimize environmental spillages from agricultural spraying equipment. Pesticide Outlook. 8, 24-27.

Tortella, G. R., Rubilar, O., Cea, M., Avendaño, M., Fernandez-Alberti, S., Diez, M.C. 2009. Chlorpyrifos degradation in a biomix of biobed system with allophonic top soil. BioMicroWorld, December 2-4, Lisbon, Portugal.
Tortella, G., Rubilar, O., Valenzuela, E., Gianfreda, L. and M.C. Diez. 2008. Enzymatic characterization of Chilean native wood-rotting fungi for potential use in the bioremediation of polluted environments with chlorophenols. World J. Microb. Biot. 24, 2805-2818.

Tortella, G., Diez, M.C., Durán, N. 2005. Fungal diversity and use in decomposition of environmental pollutants. Crit. Rev. Microbiol. 31, 197-212.

Trejo-Hernández, M., Ortiz, A., Okoh, A., Morales, D., Quintero, R. 2007. Biodegradation of heavy crude oil Maya using spent compost and sugar cane bagasse wastes. Chemosphere 68, 848-855.

Venkata Mohan, S., Sirisha, K. Chandrasekhara Rao, N., Sarma, P.N., Reddy, S.J. 2004. Degradation of chlorpyrifos contaminated soil by bioslurry reactor operated in sequencing batch mode: bioprocess monitoring. J. Hazard. Mater. 116, 39-48.

Vischetti, C., Capri, E., Trevisan, M., Casucci, C., Perucci, P. 2004. Biomassbed: a biological system to reduce pesticide point contamination at farm level. Chemosphere 55, 823-828.

Vischetti, C., Coppola, L., Monaci, E., Cardinali, A., Castillo, M.P. 2007. Microbial impact of the pesticide chlorpyrifos in Swedish and Italian biobeds. Agron. Sustain. Dev. 27, 267-272.

Vischetti, C., Monaci, E., Cardinali, A., Casucci, C., Perucci, P. 2008. The effect of initial concentration, co-application and repeated applications on pesticide degradation in a biobed mixture. Chemosphere 72(11), 1739-1743.

Wait, S.T., Thomas, D., 2003. The Characterization of base oil recovered from the low temperature thermal desorption of drill cuttings. SPE/EPA Exploration and Production Environmental Conference, Mar 10-12, San Antonio, TX, pp. 151-158. 
$\begin{array}{llll}\text { Westerberg, } & \text { K., } & \text { Elväng, } & \text { A.M., } \\ \text { Stackebrandt, E., Jansson, J.K. } & \mathbf{2 0 0 0 .}\end{array}$ Arthrobacter chlorophenolicus sp. nov., a new species capable of degrading high concentrations of 4-chlorophenol. Int. J. Syst. Evol. Microbiol. 50, 2083-2092.

Westbom, R., Hussen, A., Megersa, N., Negussie Retta, N., Mathiasson, L., Björklund, E. 2008. Assessment of organochlorine pesticide pollution in Upper Awash Ethiopian state farm soils using selective pressurized liquid extraction. Chemosphere 72, 1181-1187.

Wirén-Lehr, S., Scheunert, I., Dorfler, U. 2002. Mineralization of plant-incorporated residues of ${ }^{14} \mathrm{C}$-isoproturon in arable soils originating from different farming systems, Geoderma 105, 351-366.

Wirén-Lehr, S., Castillo, M.P., Torstensson, L., Scheunert, I. 2001. Degradation of isoproturon in biobeds. Biol.Fert. Soils 33, 535-540
Wu, J., Yu, H. 2008. Biosorption of 2,4dichlorophenol from aqueous solution by immovilized Phanerochaete chysosporium biomass in fixed-bed column. Chem. Eng. J. $138,128-135$.

Yu Y.L., Fang, H., Wang, X., Wu X.M., Shan, M., Yu, J.Q. 2006. Characterization of a fungal strain capable of degrading chlorpyrifos and its use in detoxification of the insecticide on vegetables. Biodegradation 17, 487-494.

Zhu, L., Feng, S. 2003. Synergistic solubilization of polycyclic aromatic hydrocarbons by mixed anionic-nonionic surfactants. Chemosphere 53, 459-467. 